ESJ Humanities

\title{
The Perils of Inconsistent Use of ICT-Related Terminology in School Textbooks
}

\author{
Nikolche Mickoski, (Research Associate, PhD) \\ Lexicographic Centre "Georgi Stardelov", Macedonian Academy of \\ Sciences and Arts, Republic of North Macedonia
}

Doi:10.19044/esj.2021.v17n39p35

Submitted: 18 October 2021

Accepted: 22 November 2021

Published: 30 November 2021
Copyright 2021 Author(s)

Under Creative Commons BY-NC-ND

4.0 OPEN ACCESS

Cite As:

Mickoski N. (2021). The Perils of Inconsistent Use of ICT-Related Terminology in School Textbooks. European Scientific Journal, ESJ, 17 (39), 35.

https://doi.org/10.19044/esj.2021.v17n39p35

\begin{abstract}
This paper analyses the consistency in use of appropriate ICT-related terminology in school textbooks in elementary and secondary schools that are approved by the National Textbook Committee and published by the Ministry of Education and Science of the Republic of North Macedonia. Analysis shows that ICT-related terminology is used inconsistently, and sometimes incorrectly, in the analysed textbooks. Consistent use of correct and appropriate terminology in all the textbooks will enable pupils to acquire the correct terminology and use it correctly.
\end{abstract}

Keywords: Macedonian, textbooks, ICT-related terminology, appropriate terminology, inconsistency

\section{Introduction}

School textbooks are primary source of knowledge for the pupils in elementary and secondary schools. That is the reason why they are subject to strict control and verification of the relevant institutions before publication. According to the consolidated text of the Law on school textbooks for elementary and secondary schools (Zakon za uchebnici za osnovno i sredno obrazovanie 2018), National Textbook Committee is responsible for approval of a textbook in order to be used in elementary and secondary education. The Law on school textbooks for elementary and secondary schools stipulates that each textbook shall have an author with over 10 years of experience working 
as a teacher or assistant for the relevant subject, a review committee consisted of three members, and a language editor.

This paper will explore the use of standard ICT-related terminology in ICT-related school textbooks, i.e. textbooks that belong to scientific textbooks (didactical and scientifically practical) substyle of the academic prose.

Jelinek (Jelinek 1992: 15-26) defines style as a set of additional informational properties of speech which results from the selection of figures of speech and their use in the text. According to Minova-Gjurkova (MinovaGjurkova 2003: 200), functional style is a set of norms that stipulate selection and use of language resources in certain conditions of language communication. Biber et al. in Longman Grammar of Spoken and Written English define registers as varieties relating to different circumstances and purposes (Biber et al. 1999: 15). They distinguish four major registers: conversation, fiction, news, and academic prose. The main communicative purpose/content of the academic prose is to provide information, argumentation, and explanation. Minova-Gjurkova (Minova-Gjurkova 2003: 317) distinguishes three substiles of the academic prose: strictly scientific (academic), scientific textbooks (didactical and scientifically practical) and scientifically popular.

In order to address the need of national ICT terminology, in 2008, Macedonian Ministry of Information Society established a work group consisted of 19 representatives of relevant stakeholders in information and communication technologies. The work group worked on a list of frequently used ICT-related terms which resulted in National ICT Glossary containing about 1,500 ICT-related terms and acronyms (Mickoski 2009: 367). The National ICT Glossary is the reference normative glossary for ICT-related terminology in Macedonian.

\section{Analysis}

With the intention to explore the consistent use of harmonized and adopted terminology related to information and communication technologies in textbooks, two ICT-related school textbooks were analysed: textbook Информатика за VII одделение за деветгодишно основно образование (transliterated title: Informatika za VII oddelenie za devetgodishno osnovno obrazovanie) by Andrijana Tomovska used in $7^{\text {th }}$ grade of elementary education (hereinafter Informatika za VII oddelenie) and textbook Информатика за І година на средното образование (гимназиско, средно стручно и уметничко) (transliterated title: Informatika za I godina na srednoto obrazovanie [gimnazisko, sredno struchno I umetnichko]) by Danijela Gjorgjevic used in $1^{\text {st }}$ grade of secondary education in gymnasiums, vocational, and art schools (hereinafter Informatika za I godina na srednoto obrazovanie), both published by the Ministry of Education and Science of the 
Republic of North Macedonia. The aim of the analysis was to find out whether the authors of the textbooks use the terminology defined in National ICT Glossary consistently and correctly or whether they use other terms, usually transliterated English terms obtained by the processes of transliteration, that is the representation of words written in an alphabetic script by means of another (Hartmann, James 1998: 147) or transcription, that is a process and result of representing spoken language by means of a specific notation system (Hartmann, James 1998: 146).

The analysis of the consistent use of harmonized and adopted terminology related to information and communication technologies in the two textbooks was conducted by comparison of the use of 12 frequently used terms, or translation equivalents of English ICT-related terms. The results are provided in the following table.

\begin{tabular}{|l|l|l|l|}
\hline English term & $\begin{array}{l}\text { Term used in } \\
\text { National } \\
\text { Glossary }\end{array}$ & $\begin{array}{l}\text { Term used in } \\
\text { ICTformatika za VII } \\
\text { oddelenie }\end{array}$ & $\begin{array}{l}\text { Term used in } \\
\text { Informatika } \\
\text { za I godina na } \\
\text { srednoto } \\
\text { obrazovanie }\end{array}$ \\
\hline email & е-пошта & е-маил & е-пошта \\
\hline website & веб-локација & сајт & веб-локација \\
\hline (hyper)link & врска & линк & линк / врска \\
\hline file & датотека & фајл & датотека \\
\hline driver & двигател & / & драјвер \\
\hline background & заднина & позадина & позадина \\
\hline Internet & интернет & $\begin{array}{l}\text { Интернет } \\
\text { интернет }\end{array}$ & $\begin{array}{l}\text { Интернет } \\
\text { интернет }\end{array}$ \\
\hline cell & келија & ќлија / клетка & ќелија \\
\hline command & наредба & наредба / команда & $\begin{array}{l}\text { наредба } \\
\text { команда }\end{array}$ \\
\hline folder & папка & фолдер & папка / фолдер \\
\hline editor & уредувач & едитор & едитор \\
\hline debugger & $\begin{array}{l}\text { отстранувач } \\
\text { грешки }\end{array}$ & дебагер & дебагер \\
\hline
\end{tabular}

Table 1. 12 Inappropriate terms used in two ICT-related school textbooks

English term 'email' is a compound noun consisted of "electronic" and "mail" and is used to denote messages sent between users of computer systems, the computer systems being used to hold and transport messages (Butterfield et. al. 2016: 768). These terms are translated in Macedonian as "електронска" and "пошта." Short orthographic representation in English is "e-mail" or "email" and the correct short Macedonian orthographic representation is "е-пошта". The term is correctly used in Informatika za I godina na srednoto obrazovanie, while in Informatika za VII oddelenie transliterated version of the English term is used. 
The term "website" is used to denote a collection of hyperlinked web pages owned by an individual, organization, or company (Butterfield et. al. 2016: 1734). It is a compound noun consisted of "web" and "site" and the correct translation equivalents are "веб" for "web" and "локација" for "site". The term is correctly used in Informatika za I godina na srednoto obrazovanie, while in Informatika za VII oddelenie transliterated version "cajT" of the English term "site" is used.

The term "hyperlink" is used to denote a connection between an element (e.g., word, phrase, image, etc.) in a document to somewhere else in the same document, or to a different destination on the Web' (Butterfield et. al. 2016: 946). In Macedonian, this term is translated as "хиперврска" but the short version "врска" (link) is commonly used. In Informatika za VII oddelenie, transliterated form "линк" of the English term is used, while in Informatika za I godina na srednoto obrazovanie both correct "врска" and transliterated "линк" are used.

The terms "file" and "folder" are among the terms that have been used since the introduction of the operating systems. The term "file" is used to denote a collection of information, referred to by file name (Butterfield et. al. 2016: 829) while the term "folder" is used to denote a way of organizing and storing computer files (Oxford Advanced Learner's Dictionary 2021). Although these concepts are present for quite a long time and their correct translation equivalents "датотека" for "file" and "папка" for "folder" are commonly used, the transliterated version "фолдер" for Enlgish term "folder" is still used in both textbooks. The translation equivalent "датотека" for "file" is used correctly in Informatika za I godina na srednoto obrazovanie, while in Informatika za VII oddelenie transliterated version "фајл” of the English term "file" is used.

The term "driver" is a general language word that is transformed into a term designating a concept in ICT-related terminology through the process of terminologisation. In general lexicon, a driver is "a person who drives a vehicle" (Oxford Advanced Learner's Dictionary 2021), while in information and communication technologies, it denotes a program, or part of a program, used to control the detailed operation of an input or output device connected to a computer system (Butterfield et. al. 2016: 699). Correct translation equivalent in Macedonian is “двигател", but in Informatika za I godina na srednoto obrazovanie, the transliterated version "драјвер" is used which is not suitable to Macedonian language. The term is not used at all in Informatika za VII oddelenie.

"Background" is another general language word denoting the part of a picture, photograph or view behind the main objects, people, etc. (Oxford Advanced Learner's Dictionary 2021) and the term also is used in ICT-related terminology to denote the same concept. The correct translation equivalent for 
this term in Macedonian is "заднина", but in both textbooks analysed in this paper, the incorrect term "позадина" is used.

"Internet" is a common noun which is capitalised in English, but, according to the rule number 97 of the Macedonian spelling rulebook (Cvetkovski et al. 2017: 54), terms belonging to different science and arts fields should not be capitalised. According to this rule, "интернет" should not be capitalised, but the capitalisation is not consistent in the analysed textbooks and the term occurs both as "Интернет" and "интернет".

English term "cell" has two translation equivalents in Macedonian "клетка" and "келија". However, in ICT-related terminology, this term denotes the concept of the basic unit of a spreadsheet or some other table of text, formed by the intersection of a row and column and it contains a label, value, or formula with attributes such as size, font, and colour (Butterfield et. al. 2016: 512). The correct term that is used to denote this concept in Macedonian is "ќелија" which is used in both Informatika za VII oddelenie and Informatika za I godina na srednoto obrazovanie, while the incorrect term "клетка" is used only in Informatika za VII oddelenie.

The other English term with two translation equivalents in Macedonian is the term "command". The translation equivalents are "команда" and "наредба". According to the Interpretative Dictionary of Macedonian (Koneski 2005), the term "команда" is used to denote a concept of short oral order in the army or training, while in technical terminology it is used to denote a system of devices for manual or automatic handling. On the other hand, the definition of the term "наредба" in Interpretative Dictionary of Macedonian (Koneski 2005) refers to an official oral or written request that must be realised (Koneski 2006). In ICT-related terminology, the term "command" refers to an instruction given to a computer (Oxford Advanced Learner's Dictionary 2021) and is translated with "наредба" (Ministry of Information Society 2009: 13). In the two school textbooks analysed in this paper, both terms, the correct "наредба" and incorrect "команда" are used.

The last two terms in the table are translation equivalents of "editor" and "debugger." English term "editor" is used to denote a concept of a software application that facilitates the editing of a type of data (text, image, video, audio, etc.) (Butterfield et. al. 2016: 758). Macedonian translation equivalent of this term is "уредувач" that is defined as someone who edits, brings something in order (Koneski 2014) and that translation equivalent is given in the normative National ICT Dictionary (Ministry of Information Society 2009: 21). However, despite the existing translation equivalent which is used and defined in Macedonian language, in both school textbooks analysed in this paper the transliterated version "едитор" is used which has no meaning in Macedonian. The same case is with translation equivalents of "debugger", a term used to denote a software tool that allows the internal 
behaviour of the program to be investigated (Butterfield et. al. 2016: 677-678). In National ICT Dictionary (Ministry of Information Society 2009: 21), the provided translation equivalent for the verbal form "debug" is "отстранување грешки", which means that the nominal form will be "отстранувач на грешки". However, in both school textbooks analysed in this paper, the transcribed version “дебагер" is used.

\section{Conclusion}

Conducted analysis shows that the ICT-related terminology is used inconsistently, and sometimes, incorrectly in the ICT-related textbooks used in elementary and secondary schools in the Republic of North Macedonia. Pupils in elementary schools acquire incorrect terminology which is consisted predominantly of transliterated terms. Moreover, in the secondary education, they find out that there are different terms which are used to denote the concepts they have already been familiar with and for which they have acquired certain terms.

School textbooks are not an isolated island. They are part of a big educational ecosystem. When drafting textbooks, the authors have to be aware of the adopted national ICT terminology and must use it in a consistent manner. In addition, since all textbooks must be approved by the National Textbook Committee, each textbook have to be carefully checked for consistent use of approved terminology. Moreover, National Textbook Committee have to ensure consistent use of correct and appropriate terminology in all the textbooks. In that manner, pupils will not be confused by the incorrect and inconsistent use of terminology. If school textbooks use approved terminology consistently, the pupils will acquire the correct terminology and will use it correctly.

\section{References:}

1. Biber, D. et al. (1999). Longman grammar of spoken and written English. Harrow: Longman.

2. Butterfield, A., Ngondi, G. E., \& Kerr, A. (2016). A Dictionary of Computer Science (7 ed.). Oxford: Oxford University Press.

3. Cvetkovski, Zh., Venovska-Antevska, S., Gruevska-Madzoska, S., Jacheva-Ulchar, E., Sazdov, S. (2017). Pravopis na makedonskiot literature jazik (vtoro izdanie). Skopje: Institute of Macedonian Language Krste Misirkov \& Kultura AD - Skopje. https://pravopis.mk

4. Gjorgjevic, D. (2020). Informatika za I godina na srednoto obrazovanie (gimnazisko, sredno struchno I umetnichko). Skopje: Ministry of Education and Science of the Republic of North 
Macedonia. https://www.eucebnici.mon.gov.mk/pdf/Informatika_I_MAK_comp_2020.pdf

5. Jelinek, M. (1992). Problematika definice pojmu 'styl'. Stylistyka. Opole: Uniwersytet Opolski.

6. Koneski, K. (Ed.). (2005). Tolkoven rechnik na makedonskiot jazik, tom II (Z-K). Skopje: Institute of Macedonian Language Krste Misirkov.

7. Koneski, K. (Ed.). (2006). Tolkoven rechnik na makedonskiot jazik, tom III $(\mathrm{L}-\mathrm{O})$. Skopje: Institute of Macedonian Language Krste Misirkov.

8. Koneski, K. (Ed.). (2014). Tolkoven rechnik na makedonskiot jazik, tom VI (T-Sh). Skopje: Institute of Macedonian Language Krste Misirkov.

9. Mickoski, Nikolche. (2009). Kon rabotata na nacionalnata rabotna grupa za izrabotka na leksikon od oblast ana informatichkite i komunikaciskite tehnologii. In Makedonski jazik 2009 (pp. 367-369). Skopje: Institute of Macedonian Language Krste Misirkov.

10. Ministry of Information Society. (2009). Poimnik na makedonski zborovi od oblasta na informatichkata tehnologija. Skopje. https://mioa.gov.mk/sites/default/files/pbl_files/documents/POIMNI K.pdf

11. Minova-Gjurkova, Lj. (2003). Stilistika na sovremeniot makedonski jazik. Skopje: Magor.

12. Oxford Advanced Learner's Dictionary. Oxfor: Oxford University Press. https://www.oxfordlearnersdictionaries.com

13. Tomovska, A. (2020). Informatika za VII oddelenie za devetgodishno osnovno obrazovanie. Skopje: Ministry of Education and Science of the Republic of North Macedonia. https://www.eucebnici.mon.gov.mk/pdf/Informatika\%20za\%20VII\%20oddmin.pdf

14. Zakon za uchebnici za osnovno i sredno obrazovanie. (2018). Sluzhben vesnik na Republika Makedonija No. 98/2008, 99/2009, 83/2010, 36/2011, 135/2011, 46/2012, 24/2013, 120/2013, 29/2014, $146 / 2015,217 / 2015,30 / 2016 \& 21 / 2018$.

https://mon.gov.mk/stored/document/Zakon\%20za\%20ucebnici\%20z a\%20osnovno\%20i\%20sredno\%20obrazovanie-pdf.pdf 